\title{
Long Term Testing of Solid Oxide Electrolysis Cells Under Co-Electrolysis Conditions
}

\author{
Rao, Megha; Sun, Xiufu; Hagen, Anke
}

Published in:

E C S Transactions

Link to article, DOI:

10.1149/08009.0057ecst

Publication date:

2017

Document Version

Peer reviewed version

Link back to DTU Orbit

Citation (APA):

Rao, M., Sun, X., \& Hagen, A. (2017). Long Term Testing of Solid Oxide Electrolysis Cells Under Co-Electrolysis Conditions. E C S Transactions, 80(9), 57-69. https://doi.org/10.1149/08009.0057ecst

\section{General rights}

Copyright and moral rights for the publications made accessible in the public portal are retained by the authors and/or other copyright owners and it is a condition of accessing publications that users recognise and abide by the legal requirements associated with these rights.

- Users may download and print one copy of any publication from the public portal for the purpose of private study or research.

- You may not further distribute the material or use it for any profit-making activity or commercial gain

- You may freely distribute the URL identifying the publication in the public portal

If you believe that this document breaches copyright please contact us providing details, and we will remove access to the work immediately and investigate your claim. 


\title{
Long Term Testing of Solid Oxide Electrolysis Cells Under Co-Electrolysis Conditions
}

\author{
M. Rao, X. Sun, and A. Hagen \\ Department of Energy Conversion and Storage, Technical University of Denmark, \\ Roskilde 4000, Denmark
}

\begin{abstract}
SOECs consisting of a nickel-yttria stabilized zirconia (Ni-YSZ) fuel electrode, YSZ electrolyte and lanthanum strontium cobalt ferritegadolinium doped ceria (LSCF-GDC) composite oxygen electrode were tested under co-electrolysis $\left(\mathrm{H}_{2} \mathrm{O}+\mathrm{CO}_{2}\right)$ conditions. The aim in this study was to compare the SOEC durability under co-electrolysis conditions between galvanostatic and potentiostatic modes. Specifically, the cells were operated at $0.75 \mathrm{~A} / \mathrm{cm}^{2}$ (galvanostatic) and at $1.2 \mathrm{~V}$ (potentiostatic) at $750{ }^{\circ} \mathrm{C}$ for over 1000 hours. In both modes, a larger degradation was observed initially for the first 200 hours of testing, followed by a more stable performance over longer operating times. Trends of the area specific resistance (ASR) and detailed electrochemical analysis of the cell's performance under durability conditions for both modes indicated that the degradation was predominantly due to the fuel electrode along with a slight contribution from the oxygen electrode. Microstructural analysis also confirmed the degradation of the active fuel electrode.
\end{abstract}

\section{Introduction}

For the past few decades, the use of renewable energy sources for power production has been increasing. Europe aims at producing most of its electricity through renewable energy sources by 2050, lowering greenhouse gas emissions significantly as a consequence (1). Solar and wind energy have already acquired the status of matured technologies for renewable electricity production (2-4). The larger shares of electricity from these fluctuating sources require efficient electricity storage technologies. Examples are compressed air, batteries and flywheels (3). In this context, fuel cells and electrolysis cells become interesting for both, energy production and storage. Especially, high temperature electrolysis using solid oxide electrolysis cells (SOECs) has gained significant interest, owing to the capability to convert $\mathrm{CO}_{2}$ and $\mathrm{H}_{2} \mathrm{O}$ together to produce syngas (2,4-6). Power-to-Gas (PtG) and Power-to-liquid (PtL) scenarios have gathered significant attention in the past few decades. In case of renewable energy production, intermittent energy can be stored in the form of gas or liquids through fuel production $(2,6-8)$.

SOEC is favorable for fuel production owing to its high electrical efficiency, up to $100 \%$, since part of the energy is provided by the high temperature operation, which in turns leads to less electricity input needed for the operation $(5,9)$. In case of co-electrolysis, the produced syngas can be further converted into various fuels to be used for energy storage, transportation, heating etc. $(4,6,7)$. It is of particular interest to produce methane because an extensive infrastructure for storage and distribution is already available $(2,4,6,8)$. Solid oxide cells can also 
be used to produce methane internally; however, limited research has been performed in this field (10).

Aiming at 5-10 years of operation, durability of SOECs is still one of the major challenges. Durability testing of SOEC cells has previously been reported both for steam and co-electrolysis conditions (11-14). The cells have been tested for thousands of hours under different testing conditions such as temperature, gas composition and applied current (11-17). It is a highly desirable to operate SOEC at thermoneutral voltage, i.e. the voltage where no additional heat is required for the electrolysis reaction. Therefore, potentiostatic (constant voltage) operation is an interesting choice of operation, especially from the SOEC system point of view $(2,4)$. However, due to the technical ease of galvanostatic operation and data analysis, most tests have been carried out in this mode (18). Studies of degradation mechanisms under potentiostatic operating conditions are rare (19). Comparison between galvanostatic and potentiostatic testing has not been widely reported in literature.

In this work, SOEC cells consisting of Ni-YSZ fuel electrode support, Ni-YSZ fuel electrode, YSZ electrolyte, CGO barrier layer and LSCF-CGO oxygen electrode were tested for 1055 and 1005 hours for durability under co-electrolysis conditions in galvanostatic and potentiostatic modes, respectively. Post-test SEM analysis was carried out to analyze the microstructural changes after long-term testing. Both electrochemical and microstructural analyses were used to identify the detailed degradation mechanisms in both modes.

\section{Experimental}

Three SOECs from SOLIDPower consisting of a Nickel-Yttria Stabilized Zirconia (Ni-YSZ) fuel electrode with a thickness of 220-260 $\mu \mathrm{m}$, a 6-10 $\mu \mathrm{m}$ thick YSZ electrolyte, a CGO interdiffusion barrier layer and a 40-60 $\mu \mathrm{m}$ thick composite oxygen electrode of lanthanum strontium cobalt Ferrite-gadolinium doped ceria (LSCF-CGO) were tested. The active area of the cells were $16 \mathrm{~cm}^{2}$.

The cells were tested in a test setup as described in (20,21). They were mounted on an alumina cell test house with gold and nickel as current collector contact components on the oxygen and fuel side, respectively. A gold sealing was used on the fuel side. 4 kilograms of weight was applied on top of the cell house during start up to ensure gas tight sealants and electrical contact between the cell and the contact components. The cells were heated to $800{ }^{\circ} \mathrm{C}$ at a ramp rate of $60{ }^{\circ} \mathrm{C} / \mathrm{h}$ and held for 2 hours prior to reduction. During heating, $\mathrm{N}_{2}$ and air were supplied to the fuel electrode and oxygen electrode compartment, respectively. The cells were reduced with $\mathrm{N}_{2}$ and $\mathrm{H}_{2}$ beginning from $90 \% \mathrm{~N}_{2}$ for 1 hour, eventually shifting the flow to pure $\mathrm{H}_{2}$ for $1 \mathrm{~h}$ on the fuel electrode. On the oxygen electrode, a constant air flow was maintained. Initial electrochemical characterization of the cell was performed afterwards.

Three cells were tested, named Cell A, Cell B and Cell C. Cell A only experienced reduction and an initial electrochemical characterization (fingerprint), while Cell B was tested galvanostatically for 1055 hours and Cell $\mathrm{C}$ was tested potentiostatically for 1005 hours. The fingerprint is an electrochemical characterization of the cells at $800{ }^{\circ} \mathrm{C}, 750{ }^{\circ} \mathrm{C}, 700{ }^{\circ} \mathrm{C}$ and 650 
${ }^{\circ} \mathrm{C}$. At each temperature, $\mathrm{i}-\mathrm{V}$ characterization and EIS measurements wereperformed with either air or $\mathrm{O}_{2}$ supplied to the oxygen electrode. The steam content was varied as $4 \%, 20 \%, 50 \%, 80 \%$ and $90 \%$ with $\mathrm{H}_{2}$ on the fuel electrode. Furthermore, co-electrolysis was carried out with $40 \%$ $\mathrm{H}_{2} \mathrm{O}+50 \% \mathrm{CO}_{2}+10 \% \mathrm{H}_{2}, 45 \% \mathrm{H}_{2} \mathrm{O}+45 \% \mathrm{CO}_{2}+10 \% \mathrm{H}_{2}$ and $65 \% \mathrm{H}_{2} \mathrm{O}+25 \% \mathrm{CO}_{2}+10 \% \mathrm{H}_{2}$ supplied to the fuel electrode compartment. The $10 \%$ of hydrogen excess was added in order to avoid too oxidizing atmospheres at the fuel electrode inlet. EIS measurements during fingerprint were carried at zero DC current using a Solartron 1255 frequency analyzer and an external shunt resistor in series with the cell. EIS measurements during durability tests were carried out at $0.75 \mathrm{~A} / \mathrm{cm}^{2}$ for galvanostatic operation and at $1.2 \mathrm{~V}$ during potentiostatic operation with a frequency range of $100 \mathrm{kHz}$ to $0.08 \mathrm{~Hz}$. The electrochemical durability testing of Cell B was carried out in co-electrolysis mode $\left(65 \% \mathrm{H}_{2} \mathrm{O}+25 \% \mathrm{CO}_{2}+10 \% \mathrm{H}_{2}\right)$ and galvanostatically at 0.75 $\mathrm{A} / \mathrm{cm}^{2}$ and $750{ }^{\circ} \mathrm{C}$. The fuel utilization was fixed at $48 \%$ for galvanostatic operation. Cell $\mathrm{C}$ was operated under the similar gas composition, potentiostatically at $1.2 \mathrm{~V}$ and $750{ }^{\circ} \mathrm{C}$. Analysis of the impedance data was performed using the software Ravdav (22).

Post-test analysis of the cells was performed using scanning electron microscopy (SEM). Polished cross-sections along the hydrogen/steam flow path from inlet to outlet were prepared for both cells. The cell microstructure was examined using a Supra-35 scanning electron microscope equipped with a field emission gun (FE-SEM, Carl Zeiss) and an energy-dispersive $\mathrm{X}$-ray spectrometer (EDS, Thermo Electron Corporation). For SEM imaging, low voltage (LV) SEM through an In-lens detector and an accelerating voltage of $1 \mathrm{keV}$ was employed (23). The samples were embedded in epoxy and carbon coated to avoid charging of the sample surface and to ensure a grounded connection. Fractured samples were prepared from Hydrogen inlet to outlet and were carbon coated for analysis. In-lens and SE detectors were used at $5 \mathrm{keV}$ to investigate the surface morphology of these samples.

\section{Results and Discussion}

Cell A was used as a reference for the comparison of electrochemical performance as well as microstructural analysis. Since it is of interest to run the test at co-electrolysis conditions, $\mathrm{i}-\mathrm{V}$ curves are plotted for the three cells to establish the operational conditions for long-term testing.

In Figure 1, the performances of the cells are compared in terms of $\mathrm{i}-\mathrm{V}$ characterization during fingerprint at $750{ }^{\circ} \mathrm{C}$ with $65 \% \mathrm{H}_{2} \mathrm{O}+25 \% \mathrm{CO}_{2}+10 \% \mathrm{H}_{2}$ supplied to the fuel electrode compartment and $\mathrm{O}_{2}$ supplied to the oxygen electrode compartment. The OCV values are very similar indicating a tight setup. From the $\mathrm{i}-\mathrm{V}$ curves, Cell $\mathrm{C}$ deviates slightly from the other two cells at higher current densities. However, for the current density range of interest, similar performances of all the cells can be concluded. 


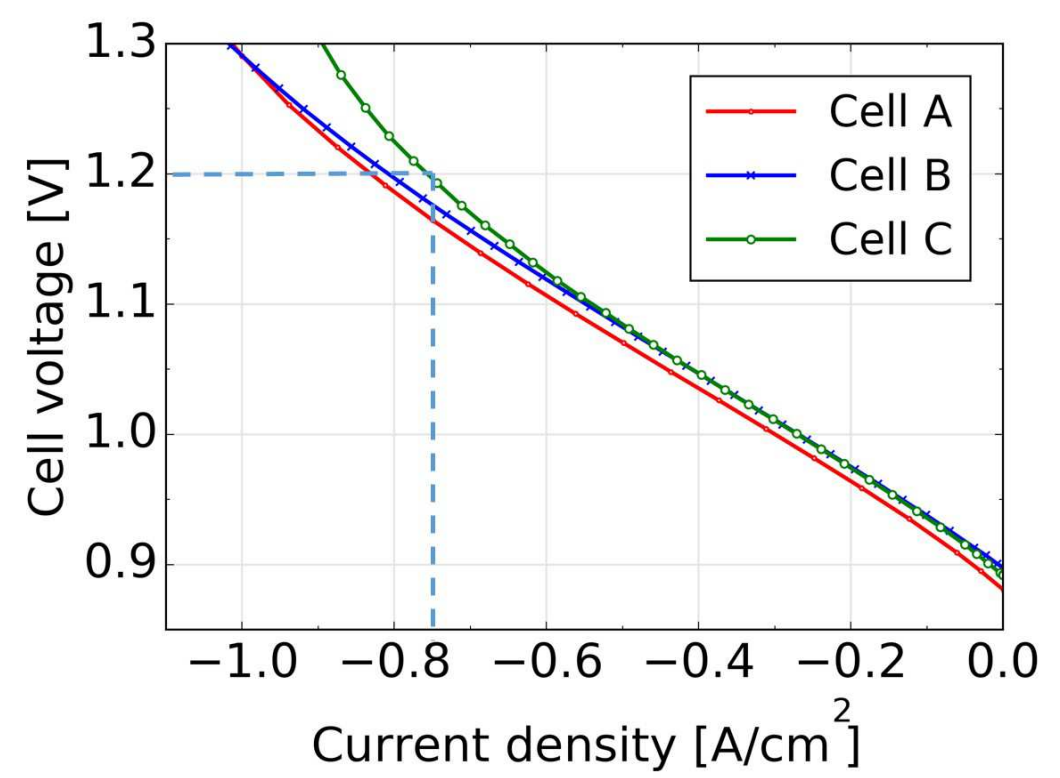

Figure 1: Initial $\mathrm{i}-\mathrm{V}$ curves of cells $\mathrm{A}, \mathrm{B}$, and $\mathrm{C}$ at $750{ }^{\circ} \mathrm{C}, 65 \% \mathrm{H}_{2} \mathrm{O}+25 \% \mathrm{CO}_{2}+10 \% \mathrm{H}_{2}$ supplied to the fuel electrode compartment and $\mathrm{O}_{2}$ supplied to the oxygen electrode compartment at 750 ${ }^{\circ} \mathrm{C}$ (Selection of operation point for durability testing is marked with broken lines.)

As mentioned earlier, it is of interest to operate the cell in potentiostatic mode and it is desirable to operate the cell at thermoneutral voltage (1.33 V for the given gas composition). However, for the given cells, such an operating voltage would yield high current densities of approximately $1 \mathrm{~A} / \mathrm{cm}^{2}$ (See Figure 1), which may result in significant degradation. From the i-V curves shown in Figure 1, similar performance can be assumed while operating at $0.75 \mathrm{~A} / \mathrm{cm}^{2}$ for cells $\mathrm{A}$ and $\mathrm{B}$, which corresponds to $1.2 \mathrm{~V}$ for Cell $\mathrm{C}$. This operating voltage was therefore chosen for the potentiostatic test and the corresponding current density for the galvanostatic test.

\section{Electrochemical Analysis}

The galvanostatic test of Cell B was performed under a constant current of $0.75 \mathrm{~A} / \mathrm{cm}^{2}$. Figure 2 shows the cell voltage and current density as a function of testing time. The voltage increased with a higher rate in the first $200 \mathrm{~h}$ of operation with a degradation rate of $0.7 \mathrm{mV} / \mathrm{h}(0.058 \%$ $/ \mathrm{h})$; later the rate is much smaller, $0.13 \mathrm{mV} / \mathrm{h}(0.009 \% / \mathrm{h})$. It is important to note that during galvanostatic testing, conversion of the gases remains unchanged and the change of the cell performance can be correlated to the degradation of specific electrodes or the electrolyte. This will be investigated in more detail, later in this work. 


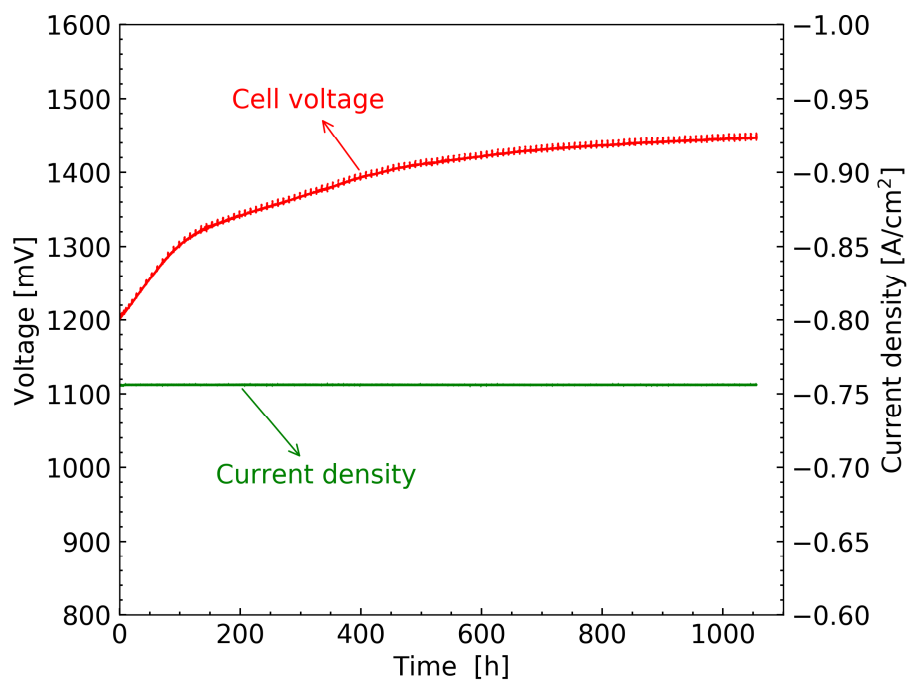

Figure 2: Current density and cell voltage evolution as function of time during the galvanostatic operation of Cell B with $65 \% \mathrm{H}_{2} \mathrm{O}+25 \% \mathrm{CO}_{2}+10 \% \mathrm{H}_{2}$ supplied to the fuel electrode compartment and $\mathrm{O}_{2}$ supplied to the oxygen electrode compartment at $750{ }^{\circ} \mathrm{C}$

The potentiostatic test on Cell $\mathrm{C}$ was carried out at $1.2 \mathrm{~V}$ and the variation of current density over testing period can be seen in Figure 3. Rapid decrease of the current density was observed in the initial $200 \mathrm{~h}$ of testing which corresponds to a high initial degradation rate of $17.18 \mathrm{mV} / \mathrm{h}$ $(0.18 \% / \mathrm{h})$. The rate of degradation for the remainder of the test was much smaller, $1.23 \mathrm{~mA} / \mathrm{h}$ $(0.0002 \% / \mathrm{h})$. In the case of potentiostatic testing, because the gas flows were kept constant the gas conversion changes over time due to the degradation of the cell. This might affect the degradation mechanisms.

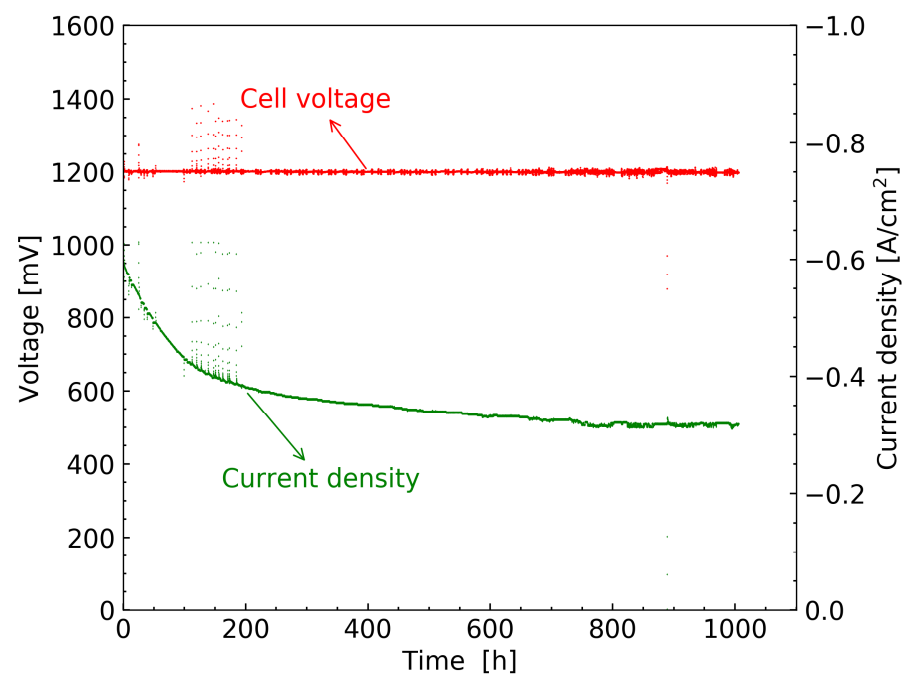

Figure 3: Current density and cell voltage evolution as function of time during the potentiostatic operation of Cell $\mathrm{C}$ with $65 \% \mathrm{H}_{2} \mathrm{O}+25 \% \mathrm{CO}_{2}+10 \% \mathrm{H}_{2}$ supplied to the fuel electrode compartment and $\mathrm{O}_{2}$ supplied to the oxygen electrode compartment at $750{ }^{\circ} \mathrm{C}$ 
For a better comparison of the cell's degradation operated in different mode, area specific resistance $(A S R)$ were calculated using the following equation:

$$
A S R=(E m f-U) / I
$$

where Emf is the electromotive force determined through the Nernst equation; it corresponds to the open circuit voltage (OCV), $U$ is the cell voltage, and $I$ is the current density.

The OCV value just before applying the durability testing conditions was used during the ASR calculation. The obtained ASR values are plotted as function of time for the two durability tests and presented in Figure 4. From the ASR trends, it is again evident that the cells degrade at a significantly higher rate during the first $200 \mathrm{~h}$ of operation (Figure 4 right axis), and thereafter gradually stabilize as already presented previously in Figure 2 and Figure 3. The ASR value increased around $9 \%$ for cell B tested under galvanostatic mode and around 14\% for cell C tested under potentiostatic mode during the first 200 hours. Afterwards, the ASR evolution are similar for both operation modes. The scatter in the ASR plot for potentiostatic testing is due to the voltage control and hence a smooth approximation of the ASR is done as shown in Figure 4.

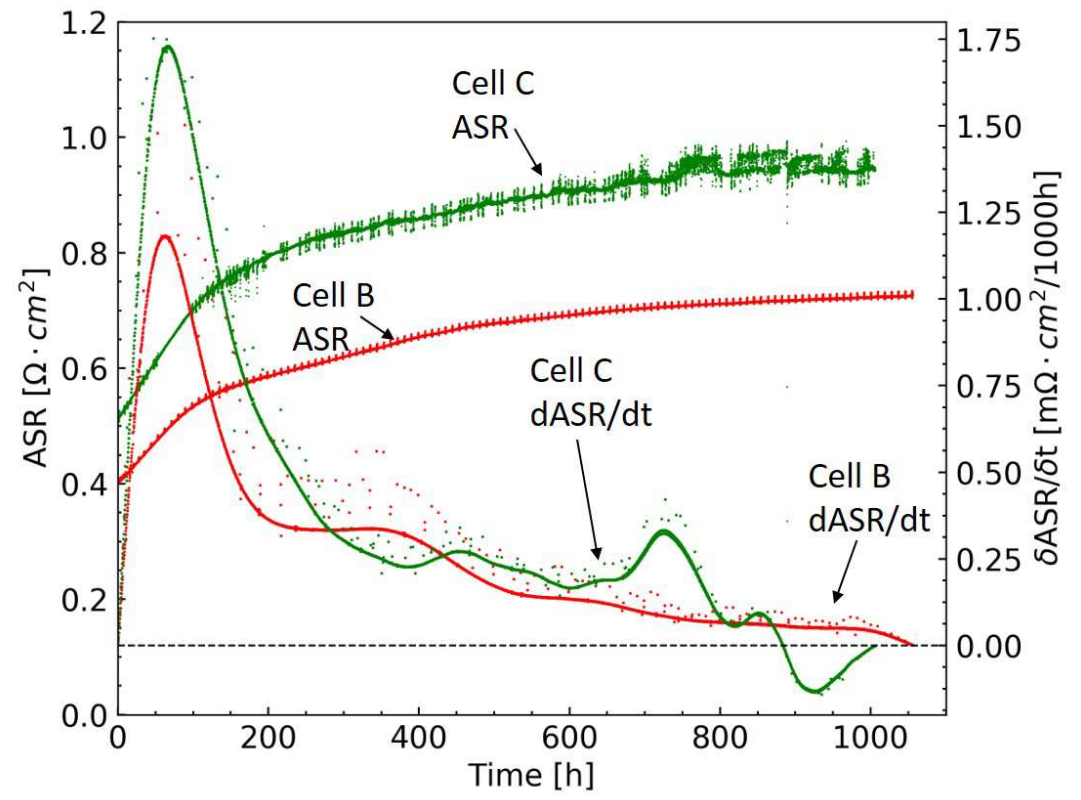

Figure 4: ASR and rate of change of ASR as a function of time, with $65 \% \mathrm{H}_{2} \mathrm{O}+25 \% \mathrm{CO}_{2}+10 \% \mathrm{H}_{2}$ supplied to the fuel electrode compartment and $\mathrm{O}_{2}$ supplied to the oxygen electrode compartment at $750{ }^{\circ} \mathrm{C}$, Cell B: $\mathrm{i}=0.75 \mathrm{~A} / \mathrm{cm}^{2}$, Cell C: V=1.2V

To understand the underlying mechanisms responsible for cell degradation, EIS spectra analysis using Distribution of Relaxation Times (DRT) method were carried out (24). To identify the mechanisms at a particular electrode, gas-shift impedance, i.e changing one electrode compartment gas composition while keep the other operation parameter constant were recorded and analyzed. 

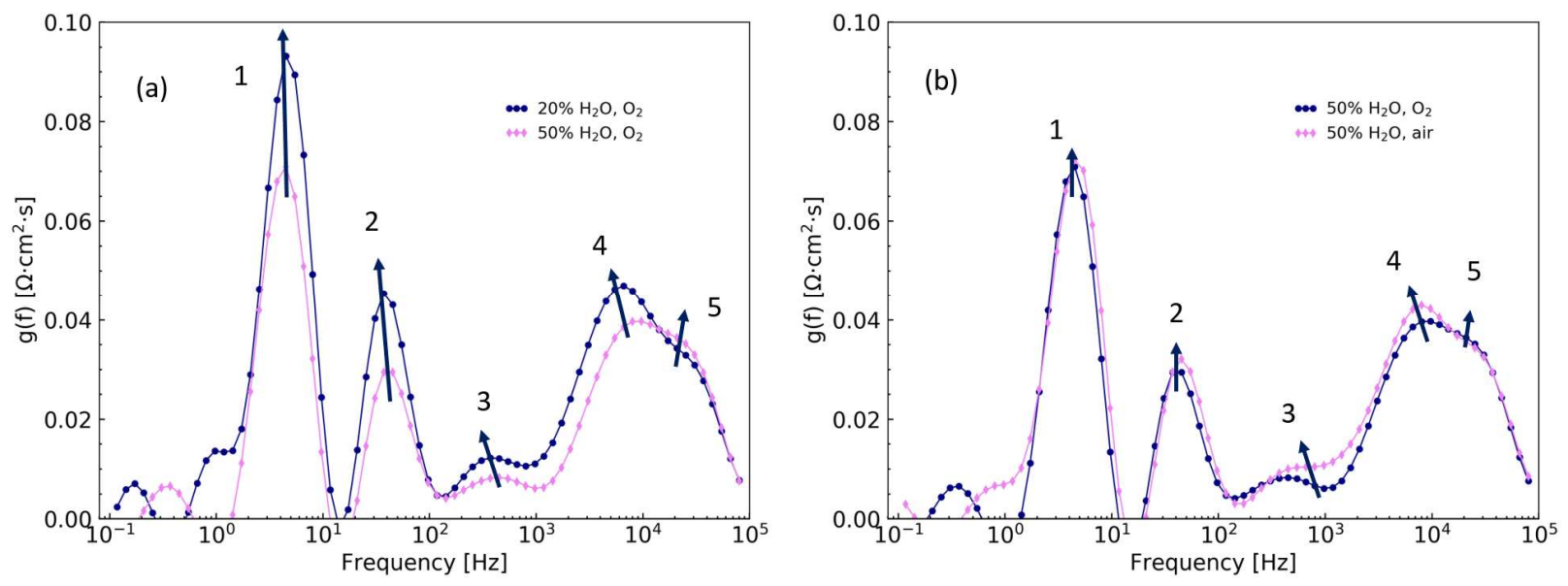

Figure 5: DRT during initial fingerprint (OCV) at $750{ }^{\circ} \mathrm{C}$ (a) fuel electrode gas shift (b) oxygen electrode gas shift

By subjecting the cell to gas shift at the fuel electrode during the initial fingerprint i.e., by varying steam composition on the fuel electrode, relaxation frequencies associated to the fuel electrode were identified (25). With the variation of the gas to the oxygen electrode from oxygen to air, the relaxation frequency associated to oxygen electrode was identified. Figure 5 (a) and (b) depict the DRT with the fuel electrode and oxygen electrode gas-shifts. Together with results from the literature $(11,26,27)$, a complete assignment to gas conversion, diffusion, and three phase boundary (TPB) processes was performed for the particular SOEC in this work. The processes along with their relaxation frequencies are listed in Table I.

Table I: Assignment of single processes SOEC under operation as a result of initial fingerprint EIS analysis using DRT(27)

\begin{tabular}{|l|l|l|}
\hline $\begin{array}{l}\text { No in } \\
\text { Figure 5 }\end{array}$ & Process & Relaxation frequency \\
\hline 1 & Gas conversion & $1-3 \mathrm{~Hz}$ \\
\hline 2 & Diffusion & $30-50 \mathrm{~Hz}$ \\
\hline 3 & Oxygen electrode & $100-1000 \mathrm{~Hz}$ \\
\hline 4 & Fuel electrode & $1-8 \mathrm{kHz}$ \\
\hline 5 & High frequency (fuel electrode) & $18-20 \mathrm{kHz}$ \\
\hline
\end{tabular}

To analyze the degradation of specific electrodes in the two operating modes, the performances of the cells were compared before and after durability (long-term) testing (see EIS in Figure 6). Significant degradation in terms of performance which can be attributed to increase of both, the serial and polarization resistance occurred as a consequence of the testing under galvanostatic conditions. The polarization contributions were investigated in more detail through DRT to identify the contribution from individual electrodes and processes. 

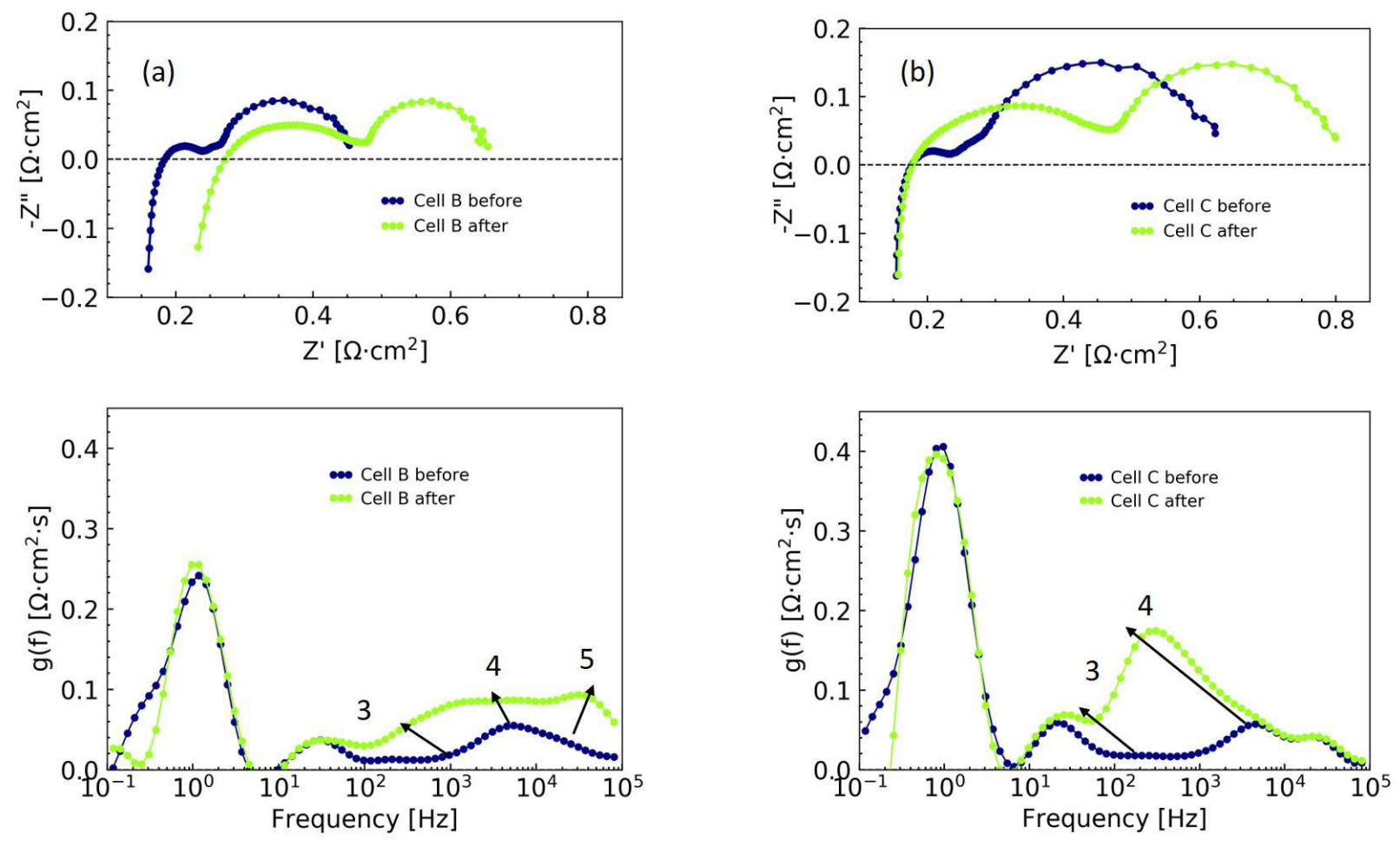

Figure 6: EIS and DRT-before and after (a) galvanostatic testing, (b) potentiostatic testing with $65 \% \mathrm{H}_{2} \mathrm{O}+25 \% \mathrm{CO}_{2}+10 \% \mathrm{H}_{2}$ supplied to the fuel electrode compartment and $\mathrm{O}_{2}$ supplied to the oxygen electrode compartment at $750{ }^{\circ} \mathrm{C}$

Comparing the DRT plots in Figure 6, both fuel and oxygen electrodes are seen to be degrading. Degradation is observed at the fuel electrode for both high frequency process (1-10 $\mathrm{kHz}$ ) and medium frequency process $(100-1000 \mathrm{~Hz})$. Previous studies have indicated the loss in percolation of Ni network to be one of the major causes for the Ni-YSZ active electrode degradation $(12-14,28)$. This phenomenon will be investigated in the microstructural analysis. Furthermore, delamination of the layers is also suggested since this would affect both serial and polarization resistance $(14,29)$.

Similarly, for potentiostatic test data analysis, impedance and DRT before and after durability are plotted in Figure 6(b). From Figure 6(b), it is obvious that the serial resistance remained constant, while the polarization resistance increased significantly. Further, DRT of the polarization resistance points towards both fuel electrode and oxygen electrode degradation at the frequency range of 500-10000 Hz, with fuel electrode processes as the predominant cause of degradation. No delamination of the layers is suggested from the electrochemical analysis as this effect would be reflected by an increase of the serial resistance as well. 
To analyze the evolution of resistances over time, impedance spectra recorded during the durability operation were plotted and can be seen in Figure 7, (a) for the galvanostatic and (b) for the potentiostatic testing, respectively. During galvanostatic operation, both Rs and Rp increased. However, in the initial $200 \mathrm{~h}$, Rs remained constant while Rp increased which is the dominant factor for high initial degradation.

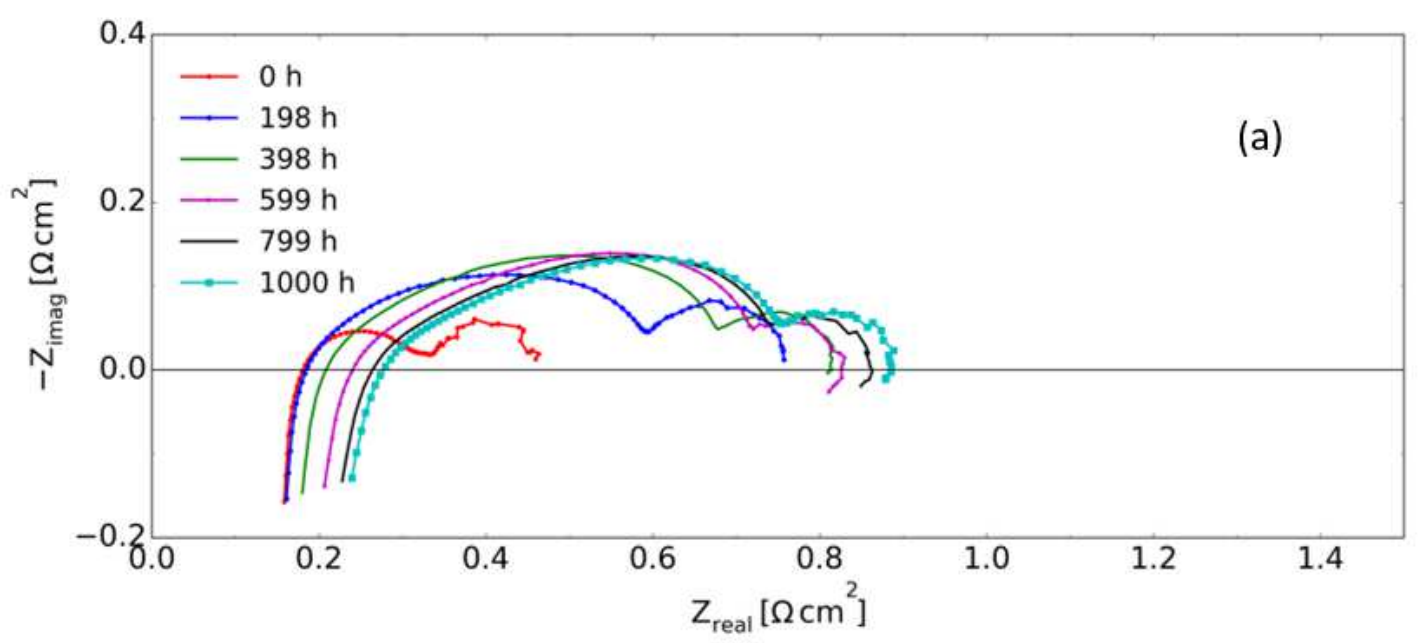

Figure 7(a): EIS over time during galvanostatic test with $65 \% \mathrm{H}_{2} \mathrm{O}+25 \% \mathrm{CO}_{2}+10 \% \mathrm{H}_{2}$ supplied to the fuel electrode compartment and $\mathrm{O}_{2}$ supplied to the oxygen electrode compartment at $750{ }^{\circ} \mathrm{C}$

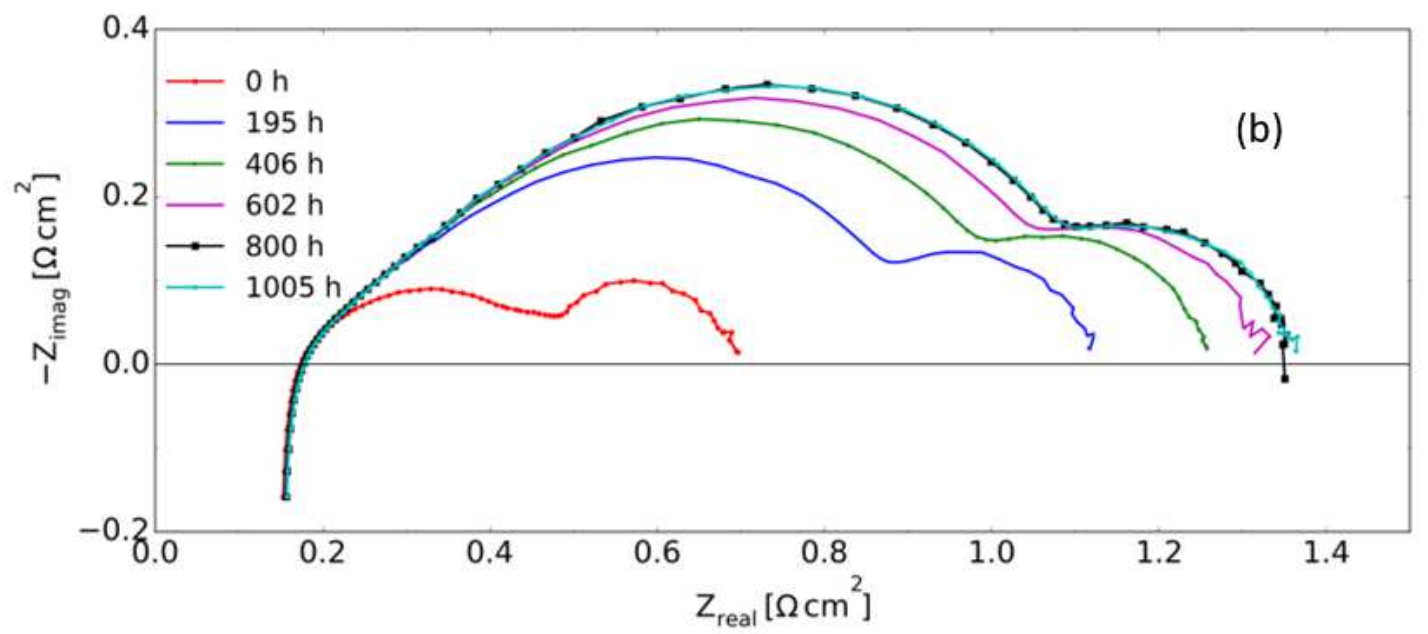

Figure 7(b): EIS over time during potentiostatic test with $65 \% \mathrm{H}_{2} \mathrm{O}+25 \% \mathrm{CO}_{2}+10 \% \mathrm{H}_{2}$ supplied to the fuel electrode compartment and $\mathrm{O}_{2}$ supplied to the oxygen electrode compartment at 750 ${ }^{\circ} \mathrm{C}$ 
The EIS during testing in potentiostatic mode as shown in Figure 7(b) confirms the findings from the EIS at OCV before and after test (see Figure 6). The polarization resistance increased continuously, particularly in the initial $200 \mathrm{~h}$ of testing, while the serial resistance remained constant over the entire potentiostatic operation period.

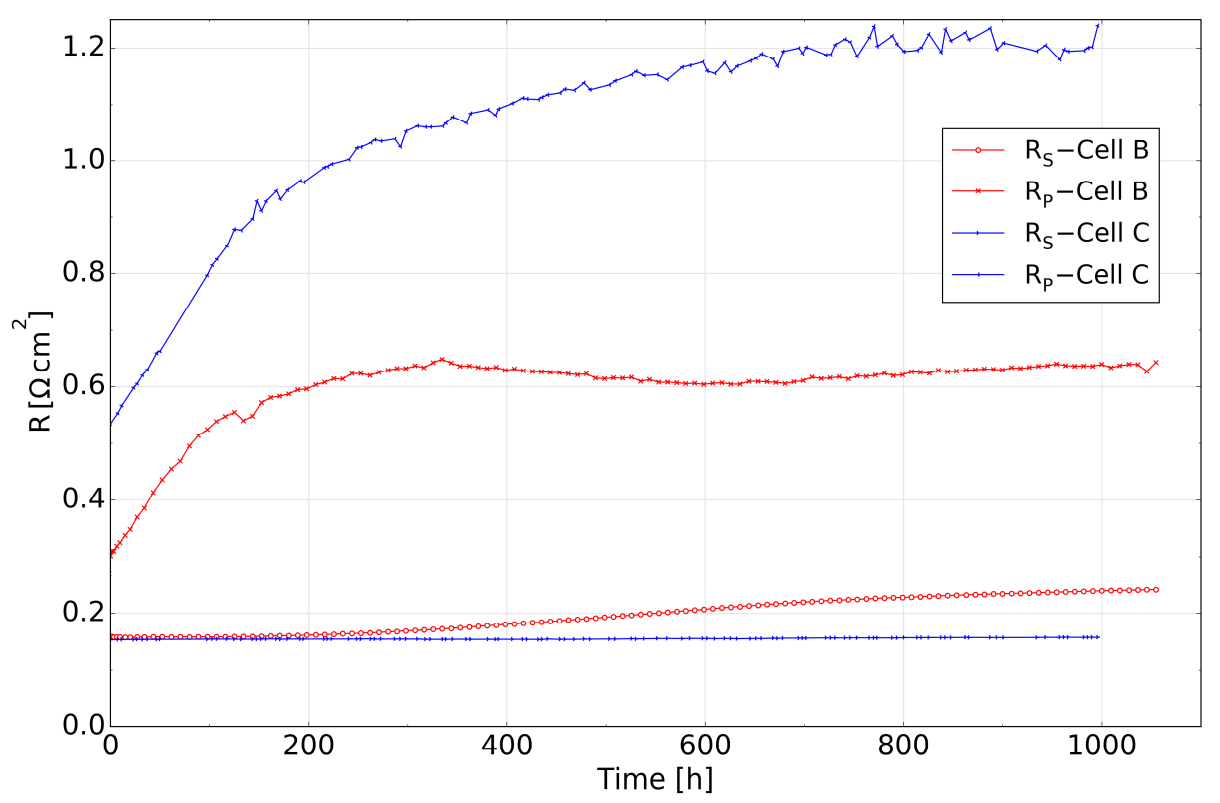

Figure 8: Variation of resistances over time for durability testing with $65 \% \mathrm{H}_{2} \mathrm{O}+25 \% \mathrm{CO}_{2}+10 \% \mathrm{H}_{2}$ supplied to the fuel electrode compartment and $\mathrm{O}_{2}$ supplied to the oxygen electrode compartment at $750{ }^{\circ} \mathrm{C}$

The overall trends of Rp and Rs of the tested Cell B and Cell Cduring the tests are shown in Figure 8. It is interesting to note that the changes in the first $200 \mathrm{~h}$ were the same in both testing modes: Rs remained constant and $\mathrm{Rp}$ increased at a high rate. This suggests similar degradation mechanisms in this period. Only after the first $200 \mathrm{~h}$, the degradation behavior starts to deviate for both modes. Then, the Rs is only increased under galvanostatic conditions. A significant increase of Rs was previously observed under conditions of high current densities/over potentials at the fuel electrode (30). It seems that running in potentiostatic mode seems to prevent this severe degradation mechanism from occurring because the current density is decreasing during testing below a critical value. In that way, the cell is "protected" from this specific degradation mechanism.

\section{Microstructural Analysis}

To complement the electrochemical results, Cells A and B were analyzed with the help of a Scanning electron Microscope (SEM). The cells were investigated at $1 \mathrm{keV}$ under Inlens detector to see the percolating Ni network. Complementary SE2 images are also shown to better visualize the phases present in the samples. 


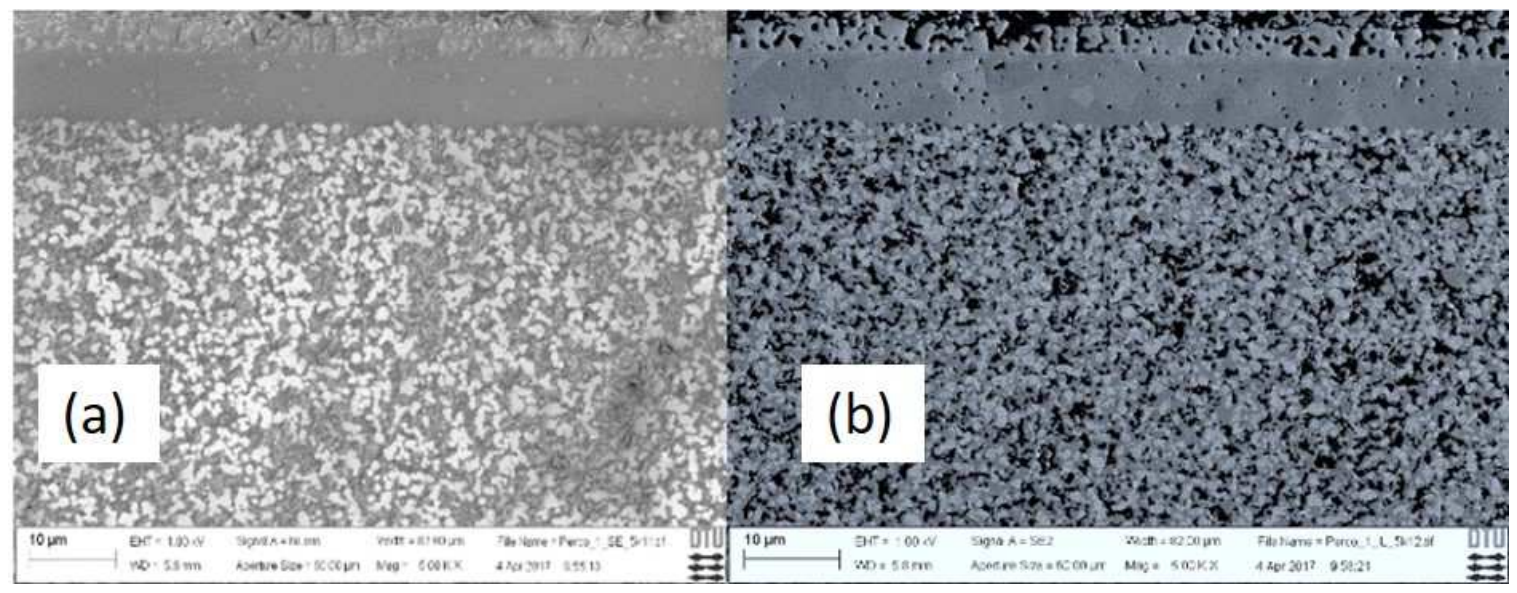

Figure 9: (a) In-lens and (b) SE-2 percolation images taken from the reference cell, 5kX magnification

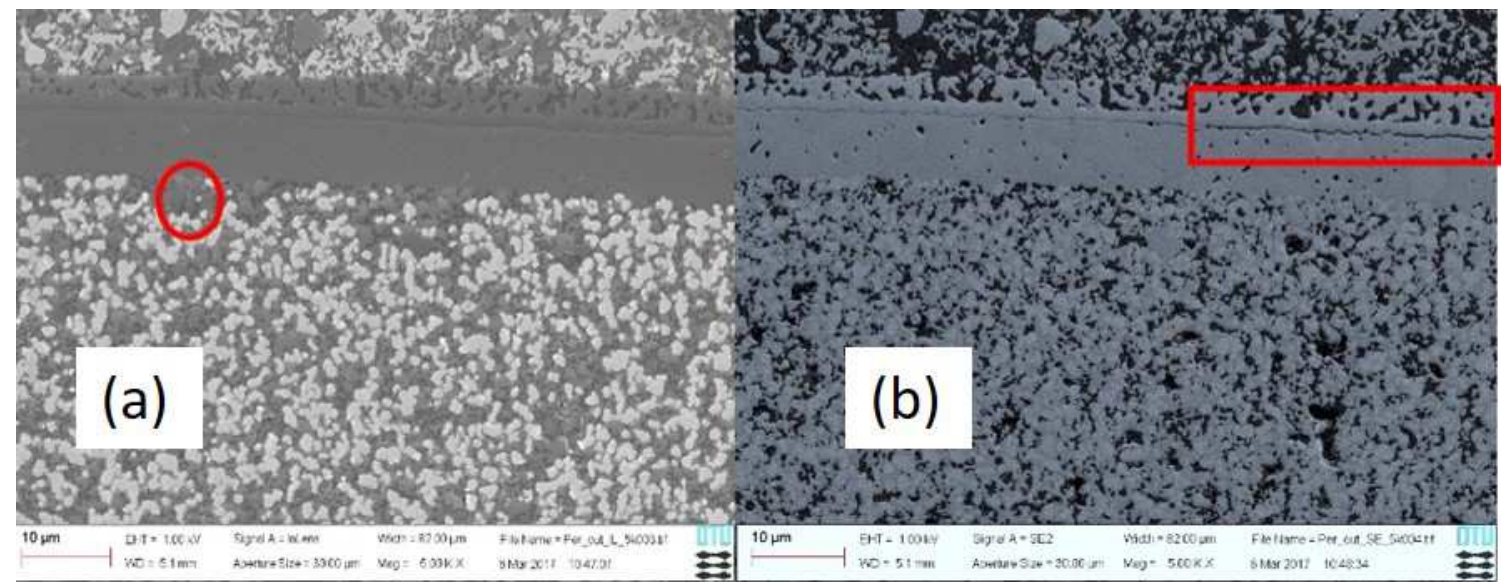

Figure 10: (a) In-lens and (b) SE-2 percolation images taken from $\mathrm{H} 2$ outlet, 5kX magnification

In Figure 9 and Figure 10, the oxygen electrode (LSCF-CGO) is on top, followed by YSZ electrolyte and the Ni-YSZ active layer and support layer for the fuel electrode at the bottom. The bright particles shown in the In-lens images are the percolating Ni particles, while the nonpercolating (isolated) Ni particles appear to be dark. In the SE-2 images, the contrast between Ni and YSZ can be seen. When compared with the reference cell in Figure 9, Ni seems to percolate to a lesser degree in the galvanostatically tested cell (specified with marker in Figure 10(a)). Predominant fuel electrode degradation was concluded from the electrochemical analysis, which is thus confirmed by the percolation images taken from hydrogen outlet in Figure 10. A loss of active TPBs seems thus responsible for the observed degradation $(13,23,28)$. A gap in the layers is observed in the outlet, at the interface of CGO and YSZ layers (see marker on Figure 10(b)). However, it cannot be excluded that this gap may have occurred during sample preparation. 


\section{Conclusion}

The cells were tested for durability in galvanostatic and potentiostatic modes to compare the degradation mechanisms. From the electrochemical analysis, degradation rates were higher in the initial 200 hours of testing which was reflected by an increase in Rp in both modes while Rs remained unchanged. This might indicate the similar underlying mechanisms which dominate the degradation in both operating modes during the first $200 \mathrm{~h}$. After the first $200 \mathrm{~h}$, degradation is slower and a difference in degradation mechanisms is observed in both modes. Particularly, Rs increases for galvanostatic mode whereas for potentiostatic mode it remains unchanged. An explanation could be due to the different overpotentials being experienced by cells in two modes. In galvanostatic mode, the overpotential remains constant and large, while it decreases in the potentiostatic mode and thus probably reaches a value that is not critical for that type of degradation. From electrochemical analysis, fuel electrode is indicated to be the main source of degradation. Initial SEM analyses indicate a loss of percolation of the Ni network which is a probable explanation for the fuel electrode degradation.

\section{Acknowledgements}

The author wishes to thank Mr. H. Henriksen, Mrs. M. Davodi, Dr. J. Bentzen and Dr. K. Thyden for their technical help with measurement and testing. The research leading to these results has received funding from the European Union`s Horizon 2020 framework program (H2020) for the Fuel Cells and Hydrogen Joint Technology Initiative under grant agreement no. 699892 (“Efficient Co-Electrolyser for Efficient Renewable Energy Storage-ECo”).

\section{References}

1. European Commission, Policy, 1-9 (2012).

2. J. Sanz-Bermejo, J. Muñoz Antón, J. Gonzalez-Aguilar, and M. Romero, Int. J. Hydrogen Energy, 40, 8291-8303 (2015).

3. A. B. Gallo, J. R. Simões Moreira, H. K. M. Costa, M. M. Santos, and E. Moutinho dos Santos, Renew. Sustain. Energy Rev., 65, 800-822 (2016).

4. E. Giglio, A. Lanzini, M. Santarelli, and P. Leone, J. Energy Storage, 1, 22-37 (2015).

5. S. D. Ebbesen, S. H. Jensen, A. Hauch, and M. B. Mogensen, Chem. Rev., 114, 1069710734 (2014).

6. J. Aicart et al., Int. J. Hydrogen Energy, 41, 17233-17246 (2016).

7. S. Mesfun et al., Renew. Energy, 107, 361-372 (2017).

8. M. Fasihi, D. Bogdanov, and C. Breyer, Energy Procedia, 99, 243-268 (2016).

9. HELMETH, http://www.helmeth.eu/index.php/technologies/high-temperatureelectrolysis-cell-soec.

10. H. Timmermann, W. Sawady, R. Reimert, and E. Ivers-Tiffée, J. Power Sources, 195, 214-222 (2010).

11. P. Hjalmarsson, X. Sun, Y. L. Liu, and M. Chen, J. Power Sources, 223, 349-357 (2013).

12. P. Hjalmarsson, X. Sun, Y. L. Liu, and M. Chen, J. Power Sources, 262, 316-322 (2014). 
13. A. Hauch, K. Brodersen, M. Chen, and M. B. Mogensen, Solid State Ionics, 293, 27-36 (2016).

14. X. Sun et al., J. Electrochem. Soc., 160, F1074-F1080 (2013).

15. S. D. Ebbesen, J. Høgh, K. A. Nielsen, J. U. Nielsen, and M. Mogensen, Int. J. Hydrogen Energy, 36, 7363-7373 (2011).

16. X. Zhang, J. E. O'Brien, R. C. O’Brien, and G. K. Housley, J. Power Sources, 242, 566574 (2013).

17. T. Kushi, Int. J. Hydrogen Energy, 42, 9396-9405 (2017).

18. A. Hauch and M. B. Mogensen, Advances in Medium and High Temperature Solid Oxide Fuel Cell Technology, (2017).

19. Y. Wang, Z. Yang, M. Han, and J. Chang, RSC Adv., 6, 112253-112259 (2016).

20. S. H. Jensen, A. Hauch, P. V. Hendriksen, and M. Mogensen, J. Electrochem. Soc., 156, B757 (2009).

21. S. D. Ebbesen, C. Graves, A. Hauch, S. H. Jensen, and M. Mogensen, J. Electrochem. Soc., 157, B1419 (2010).

22. C. Graves, (2012).

23. K. Thydén, Y. L. Liu, and J. B. Bilde-Sørensen, Solid State Ionics, 178, 1984-1989 (2008).

24. S. H. Jensen, J. Hjelm, a Hagen, and M. Mogensen, Handb. Fuel Cells, 6 (2010).

25. S. H. Jensen et al., J. Electrochem. Soc., 154, B1325 (2007).

26. A. Leonide, B. Rüger, A. Weber, W. A. Meulenberg, and E. Ivers-Tiffée, $J$. Electrochem. Soc., 157, B234-B239 (2010).

27. A. Mahmood, S. Bano, J. H. Yu, and K. H. Lee, Energy, 90, 344-350 (2015).

28. M. Chen et al., J. Electrochem. Soc., 160, F883-F891 (2013).

29. R. R. Mosbæk, J. Hjelm, R. Barfod, J. Høgh, and P. V. Hendriksen, Fuel Cells, 13, 605611 (2013).

30. R. Knibbe, M. L. Traulsen, A. Hauch, S. D. Ebbesen, and M. Mogensen, J. Electrochem. Soc., 157, B1209-B1217 (2010). 